\title{
Advanced Lung Non-Small Cell Carcinoma
}

National Cancer Institute

\section{Source}

National Cancer Institute. Advanced Lung Non-Small Cell Carcinoma. NCI Thesaurus.

Code C162158.

Lung non-small cell carcinoma that has spread extensively to other anatomic sites or is no longer responding to treatment. 